\title{
An involvement of neurokinin-1 receptor in FceRI-mediated RBL-2H3 mast cell activation
}

\author{
Xiaoyun Fang $\cdot$ Hua Hu $\cdot$ Jianhui Xie $\cdot$ Haiyan Zhu $\cdot$ \\ Dongmei Zhang $\cdot$ Wei Mo $\cdot$ Ruxin Zhang $\cdot$ Min Yu
}

Received: 18 March 2012/Revised: 2 June 2012/Accepted: 28 June 2012/Published online: 21 July 2012

(C) The Author(s) 2012. This article is published with open access at Springerlink.com

\begin{abstract}
Objective and design To determine whether the neurokinin-1 receptor (NK1R) plays a role in the activation of RBL-2H3 mast cells after Fc $\varepsilon$ RI aggregation.

Materials and methods NK1R expression in RBL-2H3 cells was inhibited by small hairpin RNA (shRNA) against NK1R, and determined by western blotting. For activation, both NK1R knockdown and control RBL-2H3 cells were sensitized by dinitrophenol (DNP)-specific IgE and
\end{abstract}

Responsible Editor: Andras Falus.

X. Fang and H. Hu contribute equally to this work and they share first authorship.

R. Zhang and M. Yu contribute equally to this work and they share corresponding authorship.

Electronic supplementary material The online version of this article (doi:10.1007/s00011-012-0523-x) contains supplementary material, which is available to authorized users.

X. Fang $\cdot$ W. Mo $\cdot$ M. Yu

The Key Laboratory of Molecular Medicine, Ministry

of Education, Shanghai 200032, People's Republic of China

X. Fang $\cdot$ J. Xie $\cdot$ H. Zhu $\cdot$ D. Zhang $\cdot$ W. Mo $\cdot$ M. Yu ( () Department of Biochemistry and Molecular Biology, Shanghai Medical College, Fudan University, Shanghai 200032,

People's Republic of China

e-mail: minyu@shmu.edu.cn

H. Hu $\cdot$ R. Zhang

Department of Otolaryngology, Huadong Hospital of Shanghai

Medical College, Fudan University, Shanghai 200032,

People's Republic of China

H. $\mathrm{Hu}$

Department of Otolaryngology, EENT Hospital of Shanghai

Medical College, Fudan University, Shanghai 200032,

People's Republic of China stimulated with the antigen DNP-bovine serum albumin (BSA). Following the activation of RBL-2H3 cells, monocyte chemoattractant protein (MCP-1) production and intracellular calcium flux were monitored by ELISA and confocal microscopy assay, respectively. For investigation of the signaling mechanism, phosphorylation of mitogenactivated protein kinases (MAPKs) after RBL-2H3 cell activation was assessed by western blotting.

Results shRNA-NK1R mediated an effective inhibition of NK1R expression in RBL-2H3 cells. Protein production of MCP-1 was reduced by more than $55 \%$ in NK1R knockdown RBL-2H3 cells compared with control RBL$2 \mathrm{H} 3$ cells. In addition, both calcium mobilization and phosphorylation levels of MAPKs (Erk1/2, JNK, and p38) after DNP-BSA stimulation (via Fc $\varepsilon$ RI) were decreased due to the inhibition of NK1R expression.

Conclusion NK1R is required for the activation of RBL$2 \mathrm{H} 3$ cells following $\mathrm{Fc} \varepsilon \mathrm{RI}$ engagement and involved in the regulation of MAPK signaling pathways.

Keywords Neurokinin-1 receptor - Mast cell · FceRI $\cdot$ Signaling pathway

\section{Introduction}

Mast cells are major effectors in allergic diseases. The activation of mast cells leads to the release of various inflammatory mediators, including vasoactive agents, cytokines, and chemokines, contributing to the disease [1]. The key receptor distributed on the surface of mast cells and responsible for their activation is the $\mathrm{IgE}$ receptor, FceRI [2]. In a typical allergic response, polyvalent antigens cross-link IgE-bearing Fc $\varepsilon$ RI molecules on mast cells. This causes the activation of immunoreceptor tyrosine- 
based activation motifs (ITAMs) in tails of FceRI and thus initiates intracellular signaling cascades that ultimately result in the activation of mast cells [1,3]. Many signal molecules have been shown to be essential for Fc\&RImediated mast cell activation, such as Src family kinases Lyn and Fyn [4-7]. However, the precise mechanism underlying mast cell activation remains far from fully understood.

NK1R is a widely expressed G protein-coupled receptor (GPCR) and the preferred receptor for neuropeptide substance P (SP) [8]. It has been revealed to be involved in various biologic responses, including pain transmission, neuroimmune modulation, exocrine secretion, and inflammation [9-13]. The close relationship between NK1R and inflammation has evidenced by the marked elevation of NK1R expression in several kinds of inflammatory diseases, such as asthma [14], acute pancreatitis [15-18], and abdominal cell adhesion formation [19, 20]. Functional expression of NK1R on bone marrow-derived mast cells (BMMCs) induced by IL4 and SCF further suggests the implications of NK1R in inflammation [21]. However, the detailed role of NK1R in allergic disorders remains unclear. Given that previous reports have demonstrated that NK1R is expressed in the RBL-2H3 cell line, a rat mast cell line with the properties of mucosal mast cells [22, 23], determining whether NK1R plays a role in Fc\&RI-induced activation of RBL-2H3 cells, will be of significance.

In this work, by inhibiting the expression of NK1R in RBL-2H3 cells, we explored potential functions that NK1R exerts in Fc\&RI-induced RBL-2H3 cell activation in an attempt to provide new insights into the mechanism underlying allergic diseases.

\section{Materials and methods}

\section{Cell culture conditions}

RBL-2H3 cell line [24] was maintained as monolayer cultures in Earle's modified Eagle's medium (MEM), supplemented with $10 \%$ heat-inactivated fetal bovine serum (FBS; HyClone), $2 \mathrm{mM}$ glutamine, $100 \mathrm{U} / \mathrm{ml}$ penicillin, and $100 \mu \mathrm{g} / \mathrm{ml}$ streptomycin at $37{ }^{\circ} \mathrm{C}$ in a humidified incubator under $5 \% \mathrm{CO}_{2}$. All cell culture reagents were obtained from Gibco except where otherwise indicated.

Plasmid construction and transfection

Two different small hairpin RNAs (shRNAs) against NK1R were designed. NK1R-shRNA (NK1R-shRNA1 and NK1R-shRNA2) constructs were produced as described previously [25]. The sequences of the oligonucleotides homologous to a 21-nucleotide segment of NK1R were: (1)
5'-GCCAGUAUCUACUCCAUGAUU-3' for NK1RshRNA1 and $5^{\prime}$-CCUACAUCAACCCAGAUCUUU- $3^{\prime}$ for NK1R-shRNA2. A scramble shRNA (negative control, Con-shRNA) was also designed. For transfection, plasmids $(2.5 \mu \mathrm{g})$ were transfected into RBL-2H3 cells using SuperFect reagent (Qiagen) according to the manufacturer's protocol. The transfected cells were harvested for further study $36 \mathrm{~h}$ later.

\section{Western blotting}

For determining the expression of NK1R, RBL-2H3 cells $\left(10^{6}\right)$ were lysed with $100 \mu \mathrm{l}$ of lysis buffer $(2 \%$ SDS, $50 \mathrm{mM}$ Tris- $\mathrm{HCl} \mathrm{pH} 6.8,4 \mu \mathrm{g} / \mathrm{ml}$ aprotinin, $20 \mu \mathrm{g} / \mathrm{ml}$ leupeptin, $2 \mu \mathrm{g} / \mathrm{ml}$ pepstatin, $2 \mu \mathrm{g} / \mathrm{ml}$ antipain, and $200 \mu \mathrm{g} /$ $\mathrm{ml}$ phenylmethylsulfonyl fluoride). The lysates were boiled for $10 \mathrm{~min}$ and protein concentrations were determined using a bicinchoninic acid (BCA) protein assay kit (Pierce Biotechnology) according to the manufacturer's instructions. The cell lysates were then mixed with $5 \times$ sample buffer and fractionated onto 10 or $12 \%$ SDS-polyacrylamide gel electrophoresis (PAGE) for NK1R analysis. After SDS-PAGE gels were run, proteins were blotted onto a polyvinylidene difluoride (PVDF) membrane (Roche Applied Science) for $90 \mathrm{~min}$ at $350 \mathrm{~mA}$. The membrane was then blocked in TBS-Tween $(0.1 \%)$ buffer containing $5 \%$ skim milk or bovine serum albumin (BSA, Amresco) for $2 \mathrm{~h}$ at room temperature (RT) followed by probing with anti-NK1R antibody (1:500-1:1,000, overnight, $4{ }^{\circ} \mathrm{C}$; Pierce Biotechnology). The membrane was washed and incubated with goat anti-rabbit IgG conjugated to horseradish peroxidase $(1: 2,000, \quad 1 \mathrm{~h}, \quad \mathrm{RT}$; Santa Cruz Biotechnology). Immunoreactive bands were visualized using enhanced chemiluminescence (ECL). The membrane was reprobed with anti-GAPDH antibody after incubation with stripping buffer (100 mM 2-mercaptoethanol, $2 \%$ SDS, $62.5 \mathrm{mM}$ Tris- $\mathrm{HCl} \mathrm{pH} \mathrm{6.8)} \mathrm{for} 30 \mathrm{~min}$ at $50{ }^{\circ} \mathrm{C}$ to control for loading. Densitometric analysis was performed by ImageJ software. Densitometry was measured in arbitrary densitometry units (ADU).

Measurement of calcium flux

RBL-2H3 cells $\left(2 \times 10^{5}\right)$ were sensitized with $0.1 \mu \mathrm{g} / \mathrm{ml}$ anti-dinitrophenol (DNP)-IgE (SPE-7 clone; SigmaAldrich) overnight and washed twice with Tyrode's buffer $\left(135 \mathrm{mM} \mathrm{NaCl}, 5 \mathrm{mM} \mathrm{KCl}, 1.8 \mathrm{mM} \mathrm{CaCl}_{2}\right.$, $1.0 \mathrm{mM} \mathrm{MgCl} 2,5.6 \mathrm{mM}$ glucose, $20 \mathrm{mM}$ HEPES, and $1 \mathrm{mg} / \mathrm{ml} \mathrm{BSA}$ at $\mathrm{pH}$ 7.4). The cells were then loaded with $4 \mu \mathrm{M}$ Fluo3-AM (Dojindo, Japan) in Tyrode's buffer for $45 \mathrm{~min}$ at $37{ }^{\circ} \mathrm{C}$ in a $5 \% \mathrm{CO}_{2}$ incubator. To monitor the calcium flux, Fluo3-loaded cells were stimulated with the antigen DNP-BSA $(10 \mathrm{ng} / \mathrm{ml})$ for the 
indicated lengths of time, and single-wavelength measurements of $\mathrm{Ca}^{2+}$-bound Fluo3 at $520 \mathrm{~nm}$ (488 nm excitation) were performed on a laser scanning confocal microscope (Leica Microsystems, Heidelberg, Germany). Images were recorded and analyzed using the "LAS AF Lite" software package (Leica), and the elevation in fluorescence intensity of $\mathrm{Ca}^{2+}$-bound Fluo3, proportional to the $\left[\mathrm{Ca}^{2+}\right]$, was calculated after subtracting the background fluorescence.

\section{ELISA for MCP-1 production}

RBL-2H3 cells $\left(3 \times 10^{6}\right)$ incubated overnight in complete MEM containing anti-DNP IgE $(0.1 \mu \mathrm{g} / \mathrm{ml})$ were washed and stimulated with DNP-BSA $(10 \mathrm{ng} / \mathrm{ml})$ for $4 \mathrm{~h}$. Cellfree supernatants were collected and secreted MCP-1 was determined using a rat-specific MCP-1 ELISA detection kit (Invitrogen).

\section{MAPK assays}

DNP-BSA-induced phosphorylation of mitogen-activated protein kinases (MAPKs) was determined by western blotting. RBL-2H3 cells were sensitized and starved overnight in serum-free MEM containing anti-DNP-IgE $(0.1 \mu \mathrm{g} / \mathrm{ml})$ and BSA $(2 \%)$. Stimulation was initiated by the addition of DNP-BSA (10 ng/ml) in Tyrode's buffer at $37^{\circ} \mathrm{C}$. The reaction was stopped by placing the cells on ice. To determine the activities of MAPK molecules, the whole cell lysates were prepared and subjected to western blotting as described above. Additional protease inhibitors including $60 \mathrm{mM} \quad \beta$-glycerophosphate, $2 \mathrm{mM}$ sodium orthovanadate, and $10 \mathrm{mM}$ sodium fluoride were added in the lysates. Anti-phospho-Erk1/2, JNK, and p38 antibodies (phospho-MAPKs) were used. To control for loading, membranes were stripped and reprobed with antibodies to total Erk1/2, JNK, and p38 (MAPKs). The intensities of the phospho-MAPKs were normalized to total MAPKs to correct for any differences in loading. All antibodies were purchased from Cell Signaling Technology unless otherwise noted and used at recommended concentrations. Aprotinin, leupeptin, pepstatin, antipain, phenylmethylsulfonyl fluoride, sodium orthovanadate, and sodium fluoride were from Sigma-Aldrich.

\section{Statistical analysis}

All data were analyzed with Prism 5 software (GraphPad Software). Data were considered statistically significant when a $P$ value was less than 0.05 , obtained with a twotailed $t$ test.

\section{Results}

shRNA-mediated knockdown of NK1R expression in RBL-2H3 cells

To determine whether NK1R plays a role in Fc\&RI-mediated RBL-2H3 cell activation, we constructed two shRNAs against NK1R (NK1R-shRNA1 and NK1R-shRNA2) and transfected them into wide-type RBL-2H3 cells to inhibit the expression of NK1R. Negative control plasmids containing scrambled shRNA (Con-shRNA) were also transfected. NK1R protein expression in RBL-2H3 cells after $36 \mathrm{~h}$ of transfection was assessed by western blotting (Fig. 1). Expression of NK1R-shRNA1 and NK1RshRNA2 led to reductions in NK1R expression of $68.43 \pm 2.41$ and $81.1 \pm 2.49 \%$, respectively, in RBL$2 \mathrm{H} 3$ cells compared with Con-shRNA. This indicates an effective knockdown of NK1R expression in RBL-2H3 cells by either NK1R-shRNA1 or NK1R-shRNA2. Hence, we named RBL-2H3 cells expressing NK1R-shRNA1 or NK1R-shRNA2 for NK1R knockdown RBL-2H3 cells and expressing Con-shRNA for control RBL-2H3 cells.
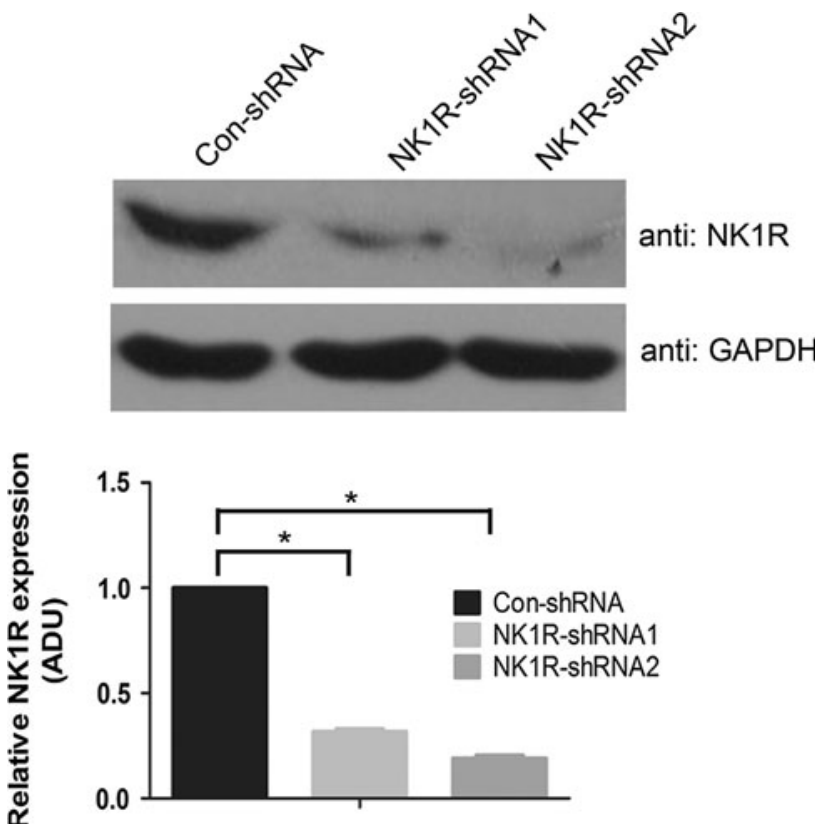

Fig. 1 An effective inhibition of NK1R expression mediated by the shRNA in RBL-2H3 cells. Upper panel wild-type RBL-2H3 cells were transfected with Con-shRNA, NK1R-shRNA1, and NK1RshRNA2 constructs. The transfected cells were harvested $36 \mathrm{~h}$ later and the effect of these three shRNA constructs on the expression of NK1R was analyzed by western blotting with anti-NK1R antibody. Representative blots from three independent experiments are shown. Lower panel densitometry analysis of NK1R expression is shown. Values normalized to GAPDH expression are represented as mean $\pm \mathrm{SD}(n=3)$ and are expressed in arbitrary densitometry units (ADU). ${ }^{*} P<0.05$ as compared with control RBL-2H3 cells, Student's $t$ test 
NK1R is required for the FceRI-evoked activation of RBL-2H3 cells

Cytokine gene expression and calcium mobilization are two remarkable events in mast cells after FceRI aggregation. To evaluate the effect of NK1R on cytokine gene expression in RBL-2H3 cells following FceRI stimulation, amounts of released MCP-1 were determined by ELISA. As shown in Fig. 2a, a significant reduction of MCP-1 expression was observed in NK1R knockdown RBL-2H3 cells $(124.1 \pm 17.7$ for NK1R-shRNA1, and 99.5 \pm 18.6 for NK1R-shRNA2) relative to control RBL-2H3 cells (278.2 \pm 23.5 for Con-shRNA). We also monitored calcium flux in both control and NK1R knockdown RBL-2H3 cells following FceRI aggregation (Fig. 2b). RBL-2H3 cells expressing either NK1R-shRNA1 or NK1R-shRNA2 showed decreased calcium mobilization compared with RBL-2H3 cells expressing Con-shRNA. These results strongly indicate an essential role of NK1R in FceRIevoked RBL-2H3 cell activation.

NK1R knockdown results in defective activation of MAPKs

Efforts were made to explore the effect of NK1R on MAPK signaling downstream of the FceRI in RBL-2H3 cells. After FceRI stimulation, phosphorylation levels of MAPKs were determined by western blotting. For phospho-Erk1/2, phosphorylation signals were hardly detected under basal conditions in both control and NK1R knockdown RBL-2H3 cells. After the antigen DNP-BSA treatment for $5 \mathrm{~min}$, control RBL-2H3 cells showed a marked increase in levels of phospho-Erk1/2. However, a much lower elevation of phosphorylation levels of Erk1/2 were observed in NK1R knockdown RBL-2H3 cells compared with control RBL-2H3 cells (Fig. 3a). Similar tendencies were observed on both phospho-JNK (Fig. 3b) and phospho-p38 (Fig. 3c). This significantly inhibited phosphorylation of MAPKs, which is attributable to the down-regulation of NK1R expression, indicates an involvement of NK1R in the regulation of MAPK signaling after FceRI aggregation in RBL-2H3 cells.

\section{Discussion}

In the present study, we demonstrate that NK1R promotes FceRI-evoked MCP-1 mRNA expression and calcium mobilization in RBL-2H3 cells. Furthermore, our results suggest that NK1R is required for the initiation of rapid, full activation of MAPKs upon FceRI aggregation in RBL$2 \mathrm{H} 3$ cells. Previous studies have revealed an involvement of NK1R in various inflammatory disorders, but little is known about the role of NK1R in FceRI-mediated allergic reactions. Our data provide the first evidence for functional roles of NK1R in the activation of RBL-2H3 cells following FceRI aggregation.

MCP-1 is one of chemokines produced by mast cells after FceRI activation [26, 27]. Given that the expression of MCP-1 was significantly reduced in Fyn-deficient BMMCs [28], Fyn kinase has been reported to be essential for the production of MCP-1 after FceRI aggregation in mast cells. Our finding that NK1R knockdown RBL-2H3 cells showed decreased MCP-1expression after antigen stimulation (Fig. 2a) suggests that NK1R is also required for the production of MCP-1 and that there perhaps exist cross-talk between NK1R and Fyn in FceRI signaling. Moreover, the decreased phosphorylation levels of JNK (Fig. 3b) and p38MAPK (Fig. 3c) observed in NK1R knockdown RBL-2H3 cells were also similar to that

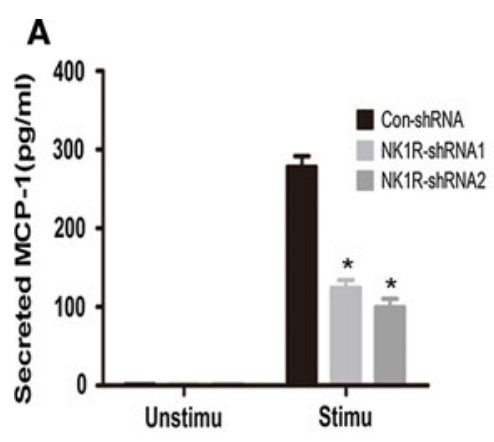

Fig. 2 NK1R promotes FceRI-induced expression of MCP-1 and calcium mobilization in RBL-2H3 cells. a Indicated RBL-2H3 cells were sensitized overnight with anti-DNP $\operatorname{IgE}(0.1 \mu \mathrm{g} / \mathrm{ml})$ and stimulated with $($ Stimu $)$ or without (Unstimu) DNP-BSA $(10 \mathrm{ng} / \mathrm{ml})$ for $4 \mathrm{~h}$ at $37^{\circ} \mathrm{C}$. Amounts of released MCP-1 in cell-free supernatants were determined by ELISA. Results are representative of three independent experiments. ${ }^{*} P<0.05$ as compared with control RBL-

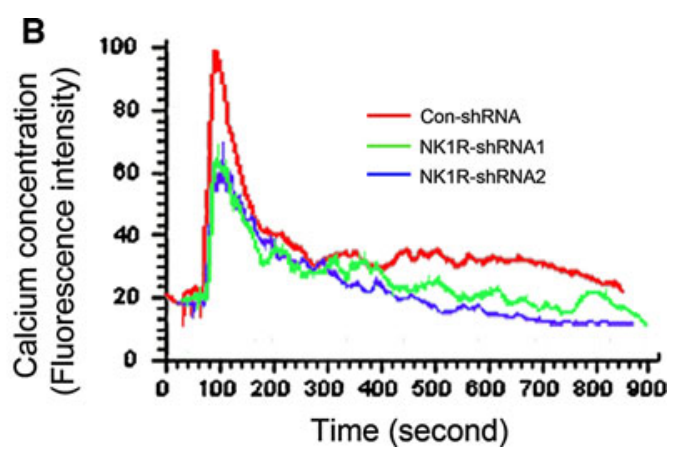

$2 \mathrm{H} 3$ cells, Student's $t$ test. b Sensitized RBL-2H3 cells were loaded with $4 \mu \mathrm{M}$ Fluo3-AM and changes in dye fluorescence with time were monitored by confocal microscopy after the addition of DNP-BSA $(10 \mathrm{ng} / \mathrm{ml})$. Calcium flux is indicated by the antigen-response curve over time. Values are presented as the mean fluorescence intensity of $\mathrm{Ca}^{2+}$-bound Fluo3 of at least 20 cells. Results of two independent experiments are shown in each panel 

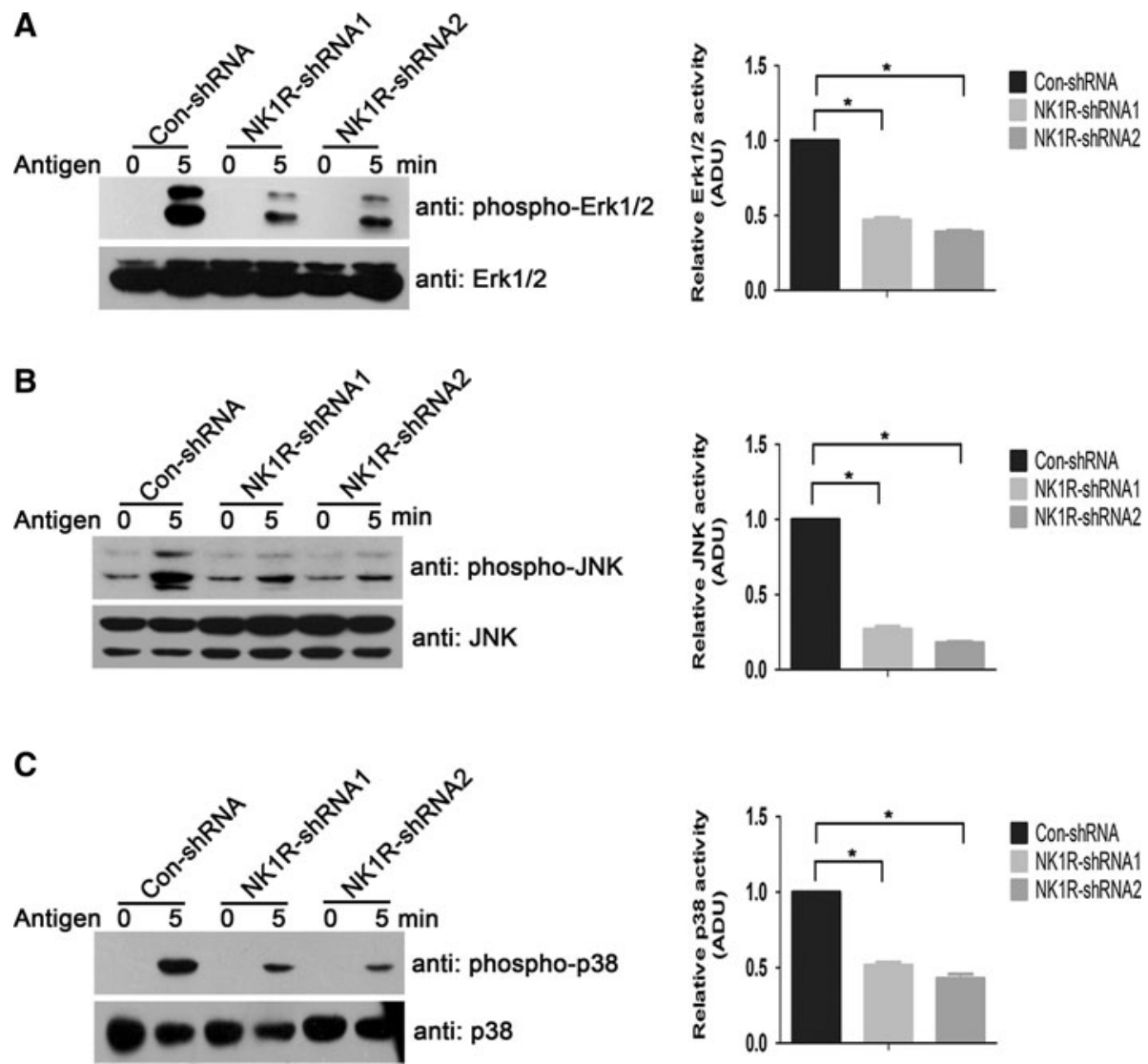

Fig. 3 NK1R contributes to the phosphorylation of MAPKs following FceRI aggregation in RBL-2H3 cells. Sensitized RBL-2H3 cells were starved and stimulated with or not with DNP-BSA $(10 \mathrm{ng} / \mathrm{ml})$ for $5 \mathrm{~min}$. The whole cell lysates were immunoblotted with phosphospecific antibodies for Erk1/2 (a), JNK (b), and p38 (c), respectively. To control for loading, the blots were stripped and reprobed with antitotal Erk1/2, JNK, and p38 antibodies, respectively. Representative blots of at least three independent experiments are shown. The levels of phospho-MAPKs (at $5 \mathrm{~min}$ ) were normalized to the expression of

reported in Fyn-deficient BMMCs [28]. Activities of MAPKs are required for the MCP-1 gene expression in mast cells [29]. Based on these results, it is possible that NK1R promotes the FceRI-induced MCP-1 expression through Fyn kinase. Actually, in mouse pancreatic acinar cells, NK1R has been demonstrated to mediate the production of MCP-1 via Src family kinases following the stimulation of SP [30]. More experiments are needed to be carried out to delineate the relationship between NK1R and Fyn in mast cells.

As with the reduced MCP-1 expression, we found that calcium flux was also inhibited as a consequence of the knockdown of NK1R expression in RBL-2H3 cells (Fig. 2b). This is as we expected, because the release of inflammatory mediators is always coupled with the elevation of intracellular calcium concentration following the activation of mast cells [7, 26]. FceRI-evoked calcium mobilization in mast cells involves the activation of
MAPKs and qualified by densitometry in ADU. The phosphorylation levels of Erk1/2 decreased by $52.99 \pm 2.84 \%$ for NK1R-shRNA1 and $60.96 \pm 1.88 \%$ for NK1R-shRNA2; of JNK decreased by $73.08 \pm 3.66 \%$ for NK1R-shRNA1 and $81.97 \pm 1.33 \%$ for NK1RshRNA2; and of p38 decreased by $48.33 \pm 3.51 \%$ for NK1RshRNA1 and $57 \pm 4.58 \%$ for NK1R-shRNA2, as compared with Con-shRNA. Values are expressed as mean $\pm \mathrm{SD}(n=3) . * P<0.05$ as compared with the control RBL-2H3 cells, Student's $t$ test

phospholipase C (PLC) [26, 31]. The activated PLC is capable of inducing the production of diacylglycerol (DAG) and inositol 1,4,5-trisphosphate (IP3), both of which are required for calcium mobilization, leading to increased calcium concentration [32]. Previous studies have demonstrated that NK1R, as a GPCR, is coupled to $\mathrm{Gq} / 11$ receptor. This receptor is associated with PLC [33]. These clues allow us to assume that the inhibition of NK1R expression in RBL-2H3 cells may impair the interaction of Gq/11 with PLC, resulting in reduced activity of PLC followed by decreased calcium flux after FceRI stimulation. This assumption might be reasonable considering that the NK1R expressed in RBL-2H3 cells is in its full-length form (407aa). In fact, NK1R has two naturally occurring forms: a full-length NK1R (407aa) isoform and a truncated NK1R (311aa) isoform lacking 96-aa residues in the carboxyl terminus [34]. The absent C-terminal domain is required for the coupling to $\mathrm{Gq} / 11$ receptor, making the 
truncated NK1R disassociated with PLC [8, 33] and unable to prime calcium mobilization by itself.

The functional role of NK1R in FceRI signaling is further confirmed by the observation that the phosphorylation of Erk1/2 was defective in NK1R knockdown RBL-2H3 cells (Fig. 3a). This, in addition to similar defects found on phospho-JNK (Fig. 3b) and phospho-p38MAPK (Fig. 3c), indicates a critical role of NK1R in MAPK signaling downstream of the FceRI in RBL-2H3 cells. The activation of NK1R by DNP-BSA (via FceRI) is virtually identical to that by SP, resulting in the expression of MCP-1 as well as the phosphorylation of MAPKs [35]. Previous investigations of the signaling mechanism have revealed that SP activation of NK1R induces the phosphorylation of Erk1/2 involves $\beta$-arrestin/src or $\beta$-arrestin2 [36]. Whether this mechanism is reasonable to explain the role of NK1R in FceRI signaling awaits further exploration. In addition, the question of how NK1R is activated and then involved in the following signaling events after FceRI cross-linking is still elusive and needs more attention in further study.

In conclusion, our data suggest that NK1R functions as a regulator in the activation of RBL-2H3 cells through FceRI signaling. In this way, they contribute to the understanding of the mechanisms underlying allergic diseases.

Acknowledgments This work was supported by grants from the National Natural Science Foundation of China (No. 30870565 and 30872848).

Open Access This article is distributed under the terms of the Creative Commons Attribution License which permits any use, distribution, and reproduction in any medium, provided the original author(s) and the source are credited.

\section{References}

1. Abramson J, Pecht I. Regulation of the mast cell response to the type 1 Fc epsilon receptor. Immunol Rev. 2007;217:231-54.

2. Kraft S, Novak N. Fc receptors as determinants of allergic reactions. Trends Immunol. 2006;27:88-95.

3. Kambayashi T, Larosa DF, Silverman MA, Koretzky GA. Cooperation of adapter molecules in proximal signaling cascades during allergic inflammation. Immunol Rev. 2009;232:99-114.

4. Eiseman E, Bolen JB. Engagement of the high-affinity $\operatorname{IgE}$ receptor activates src protein-related tyrosine kinases. Nature. 1992;355:78-80.

5. Furumoto Y, Gomez G, Gonzalez-Espinosa C, Kovarova M, Odom S, Ryan JJ, et al. The role of Src family kinases in mast cell effector function. Novartis Found Symp. 2005;271:39-47. (discussion 47-53, 95-9).

6. Odom S, Gomez G, Kovarova M, Furumoto Y, Ryan JJ, Wright $\mathrm{HV}$, et al. Negative regulation of immunoglobulin E-dependent allergic responses by Lyn kinase. J Exp Med. 2004;199: 1491-502.

7. Parravicini V, Gadina M, Kovarova M, Odom S, Gonzalez-Espinosa C, Furumoto Y, et al. Fyn kinase initiates complementary signals required for IgE-dependent mast cell degranulation. Nat Immunol. 2002;3:741-8.

8. Douglas SD, Leeman SE. Neurokinin-1 receptor: functional significance in the immune system in reference to selected infections and inflammation. Ann N Y Acad Sci. 2011;1217:83-95.

9. Bost KL. Tachykinin-mediated modulation of the immune response. Front Biosci. 2004;9:3331-2.

10. Satake H, Kawada T. Overview of the primary structure, tissuedistribution, and functions of tachykinins and their receptors. Curr Drug Targets. 2006;7:963-74.

11. Almeida TA, Rojo J, Nieto PM, Pinto FM, Hernandez M, Martin JD, et al. Tachykinins and tachykinin receptors: structure and activity relationships. Curr Med Chem. 2004;11:2045-81.

12. O'Connor TM, O'Connell J, O'Brien DI, Goode T, Bredin CP, Shanahan F. Therole of substance $\mathrm{P}$ in inflammatory disease. J Cell Physiol. 2004;201:167-80.

13. Ebner K, Singewald N. The role of substance P in stress and anxiety responses. Amino Acids. 2006;31:251-72.

14. Lambrecht BN, Germonpre PR, Everaert EG, Carro-Muino I, De Veerman M, de Felipe C, et al. Endogenously produced substance $\mathrm{P}$ contributes to lymphocyte proliferation induced by dendritic cells and direct TCR ligation. Eur J Immunol. 1999;29:3815-25.

15. Vera-Portocarrero LP, Westlund KN. Attenuation of nociception in a model of acute pancreatitis by an NK-1 antagonist. Pharmacol Biochem Behav. 2004;77:631-40.

16. Broccardo M, Linari G, Agostini S, Amadoro G, Carpino F, Ciotti MT, et al. Expression of NK-1 and NK-3 tachykinin receptors in pancreatic acinar cells after acute experimental pancreatitis in rats. Am J Physiol Gastrointest Liver Physiol. 2006;291:G518-24.

17. Bhatia M, Saluja AK, Hofbauer B, Frossard JL, Lee HS, Castagliuolo I, et al. Role of substance $\mathrm{P}$ and the neurokinin 1 receptor in acute pancreatitis and pancreatitis-associated lung injury. Proc Natl Acad Sci USA. 1998;95:4760-5.

18. Lau HY, Wong FL, Bhatia M. A key role of neurokinin 1 receptors in acute pancreatitis and associated lung injury. Biochem Biophys Res Commun. 2005;327:509-15.

19. Reed KL, Stucchi AF, Leeman SE, Becker JM. Inhibitory effects of a neurokinin-1 receptor antagonist on postoperative peritoneal adhesion formation. Ann N Y Acad Sci. 2008;1144:116-26.

20. Reed KL, Fruin AB, Bishop-Bartolomei KK, Gower AC, Nicolaou M, Stucchi AF, et al. Neurokinin-1 receptor and substance $\mathrm{P}$ messenger RNA levels increase during intraabdominal adhesion formation. J Surg Res. 2002;108:165-72.

21. van der Kleij HP, Ma D, Redegeld FA, Kraneveld AD, Nijkamp FP, Bienenstock J. Functional expression of neurokinin 1 receptors on mast cells induced by IL-4 and stem cell factor. J Immunol. 2003;171:2074-9.

22. Cooke HJ, Fox P, Alferes L, Fox CC, Wolfe SA Jr. Presence of NK1 receptors on a mucosal-like mast cell line, RBL-2H3 cells. Can J Physiol Pharmacol. 1998;76:188-93.

23. Furukawa Y, Furuno T, Teshima R, Nakanishi M. Calcium signals in rat basophilic leukemia (RBL-2H3) cells primed with the neuropeptide substance P. Biol Pharm Bull. 2001;24:1060-3.

24. Barsumian EL, Isersky C, Petrino MG, Siraganian RP. IgEinduced histamine release from rat basophilic leukemia cell lines: isolation of releasing and nonreleasing clones. Eur J Immunol. 1981;11:317-23.

25. Hu H, Zhang R, Fang X, Yu M, Yu S, Zhang J, et al. Effects of endogenous substance $\mathrm{P}$ expression on degranulation in RBL2H3 cells. Inflamm Res. 2011;60:541-6.

26. Saitoh S, Arudchandran R, Manetz TS, Zhang WG, Sommers CL, Love PE, et al. LAT is essential for Fc epsilon RI-mediated mast cell activation. Immunity. 2000;12:525-35.

27. Feuser K, Thon KP, Bischoff SC, Lorentz A. Human intestinal mast cells are a potent source of multiple chemokines. Cytokine. 2012;58:178-85. 
28. Gomez G, Gonzalez-Espinosa C, Odom S, Baez G, Cid ME, Ryan JJ, et al. Impaired FcepsilonRI-dependent gene expression and defective eicosanoid and cytokine production as a consequence of Fyn deficiency in mast cells. J Immunol. 2005;175:7602-10.

29. Gibbs BF, Wolff HH, Zillikens D, Grabbe J. Differential role for mitogen-activated protein kinases in IgE-dependent signaling in human peripheral blood basophils: in contrast to p38 MAPK, c-Jun N-terminal kinase is poorly expressed and does not appear to control mediator release. Int Arch Allergy Immunol. 2005;136: 329-39.

30. Ramnath RD, Sun J, Bhatia M. Involvement of SRC family kinases in substance P-induced chemokine production in mouse pancreatic acinar cells and its significance in acute pancreatitis. J Pharmacol Exp Ther. 2009;329:418-28.

31. Gu HH, Saito K, Klaman LD, Shen JQ, Fleming T, Wang YP, et al. Essential role for Gab2 in the allergic response. Nature. 2001;412:186-90.

32. Scharenberg AM, El-Hillal O, Fruman DA, Beitz LO, Li Z, Lin S, et al. Phosphatidylinositol-3,4,5-trisphosphate (PtdIns-3,4,5-P3)/
Tec kinase-dependent calcium signaling pathway: a target for SHIP-mediated inhibitory signals. EMBO J. 1998;17:1961-72.

33. Tuluc F, Lai JP, Kilpatrick LE, Evans DL, Douglas SD. Neurokinin 1 receptor isoforms and the control of innate immunity. Trends Immunol. 2009;30:271-6.

34. Lai JP, Lai S, Tuluc F, Tansky MF, Kilpatrick LE, Leeman SE, et al. Differences in the length of the carboxyl terminus mediate functional properties of neurokinin-1 receptor. Proc Natl Acad Sci USA. 2008; 105:12605-10.

35. Ramnath RD, Sun J, Adhikari S, Bhatia M. Effect of mitogenactivated protein kinases on chemokine synthesis induced by substance $\mathrm{P}$ in mouse pancreatic acinar cells. J Cell Mol Med. 2007;11:1326-41.

36. DeFea KA, Vaughn ZD, O’Bryan EM, Nishijima D, Dery O, Bunnett NW. The proliferative and antiapoptotic effects of substance $\mathrm{P}$ are facilitated by formation of a beta-arrestin-dependent scaffolding complex. Proc Natl Acad Sci USA. 2000;97:11086-91. 